\title{
MODERN MARKETING CONCEPTS AS THE BASIS FOR FORMATION AND INCREASE OF THE ATTRACTIVENESS OF CITIES AND TERRITORIES
}

\author{
Iryna BUDNIKEVYCH ${ }^{1}$, Iryna GAVRYSH ${ }^{2}$ \\ Yuriy Fedkovych Chernivtsi National University, Ukraine
}

\begin{abstract}
Instruments of formation and increase of attractiveness of the territory within the framework of modern marketing conceptions, the role of marketing complex elements in shaping the attractiveness of the territories are examined, separate economical categories, forming notional instrument of the attractiveness of the territories are specified and proposals concerning the directions of marketing efforts are formulated. Methodology. Theoretical and methodological basis of the research is the work of scientists on marketing problems of the city, theory of I. Budnikevych, identifying the characteristics of territorial marketing (municipal, city marketing) within industrial, commodity, sale, classical, social-ethic and partnership conceptions. The authors used the combination of following methods in the process of scientific investigation: method of generalization and scientific abstraction - for concrete definition of notional-categorial apparatus; analytical monographic method - to represent scientific thoughts on the directions of marketing instruments application in the processes of territorial attractiveness management; comparative analysis - to find out the peculiarities of marketing instruments and methods use within the limits of different concepts and at different stages of territorial development. Practical value. It was defined that territorial marketing system allows to expand traditional approaches to the policy of regional and local authority's attractiveness, supplementing them with modern components and characteristics. Nowadays, the instruments of situational conceptions are still actively applied by homeland and foreign territorial marketing practice, sale conception in particular, which stipulates the direction of territorial authorities' activity to satisfy territorial needs. The instruments of modern territorial marketing conceptions allow to form and increase the attractiveness of territories for defined target audiences. Using the instruments of municipal marketing social-ethic conception one can focus target audiences' attention on social, ecological and economical territorial attractiveness ensuring stable territorial development. Territorial marketing within the framework of partnership conceptions as the philosophy of territorial (region, city) functioning based on the formation, support and development of mutually beneficial long-term relations between the participants of interaction will create new common values, obtaining and sharing advantages of this activity. The development of the relations between territory and its target audiences defines and forms the basis of the environment to make decisions as to the habitation, visiting, conducting business, investment etc., i. e. forms specific territory's (country, region, city, settlement) attractiveness. Novelty. On the basis of this research the authors proposed to consider marketing approach to territorial (regional, urban) attractiveness as a transition to long-term development in the field of systematic management on the basis of consumers' demands orientation and partnership, clear definition of target audience and its demands, flexible regional policy, applying both traditional and non-traditional instruments to form, improve, support and, sometimes, decrease the attractiveness of territory with demarketing means. Conclusions. It has been determined, that according to marketing approach, the attractiveness of the territory is - the ideas total about properties and features, factors and conditions, limits and possibilities, means and instruments, providing satisfaction and the perspective of increase of target audiences' needs while they choose a proper region for activity and organize their loyalty towards the territory (region, city). Marketing policy of the attractiveness of territories is proposed as a complex of measures aimed at attracting target audience's attention, it's being worked out and realized by territorial bodies (members of the community take active part) and it is the element of territorial programs and development strategy. Marketing efforts should be fixed on the increase of territorial attractiveness not only for the inhabitants but for other target groups - tourists, visitors, investors, population and entrepreneurs from other cities, subjects of regional, national
\end{abstract}

\footnotetext{
Corresponding author:

${ }^{1}$ Department of Marketing, Innovation and Regional Development, Yuriy Fedkovych Chernivtsi National University.

E-mail: budnikevich@mail.ru

${ }^{2}$ Department of Marketing, Innovation and Regional Development, Yuriy Fedkovych Chernivtsi National University.

E-mail: ira_vision@mail.ru
} 
and international levels. Investment, settlement, social, business, innovation, tourist and educational attractiveness will favour long-term paretnership formation with target audiences. Marketing instruments ensure long-term relations, helping to increase an transform territorial image, provide loyalty of all the subjects, objects and contact territorial audience, and they are one of the most complex and effective mechanisms of formation and increase of the attractiveness of territories, their promotion in internal and external social-economic environment.

Key words: marketing conceptions, city marketing, municipal marketing, classical marketing conception, socialethic marketing conception, relationship conception, marketing techniques, marketing influence, attractiveness of territories, marketing approach, marketing policy of attractiveness.

JEL Classification: A11, R19, P49

\section{Introduction}

The quality of urban development management in new conditions of postindustrial society and further development of economical knowledge demands focusing on the newest approaches in such management organizations. Managerial efforts should be oriented on target audiences demands, urban resource potential and mostly based on intellectual, informative, managerial, cultural-patriotic and national-ethic needs. The necessity to form the systems of territorial (regional) management focused on target audiencies demands satisfaction and economic, ecological, social, cultural factors balancing, defines actuality of marketing approach to this kind of management.

Marketing as the system of principles and mechanisms, the complex of means and instruments aimed to learn consumers' needs and involve them into the process of socially useful values creation gives the opportunity to form a qualitative new territorial product, to provide the system of functioning and further stable development of all public institutions and local authorities with a new content. These institutions are aimed at providing urban social economic development and obtaining social economic effect (the increase of population's well being and living standards, comfortable living conditions, formation of favourable entrepreneurship and investment environment etc.).

According to the marketing approach the territory attraction is a reflection of the degree of satisfaction of the needs and expectations of target audiences. Attractiveness is a potential of the territory from the viewpoint of the satisfaction degree and perspective growth of the needs of target audiences in case of their choice of territory (city, region, country) for activity (visiting, habitation, investment, etc.) taking into account the objectives and their capabilities. Based upon the priority target audiences and their needs there are made not only reasonable decisions in territorial management, but also territorial development strategies are developed.

The problem of territorial attraction, its formation, evaluation and increase is reflected in scientific works by A. Asaul, I. Blank, V. Hramotnev and N. Bobrytska, N. Bryukhovetska, V. Demydovych, S. Zelenskyi, M. Lesechko, O. Mykhailenko, M. Oklander,
O. Yastremska, V. Hob and many others. Marketing approach to territorial attractiveness is analysed in the works by I. Budnikevych, M. Butko, V. Vakulenko, D. Vizgalov, V. Homolska, F. Kotler, O. Lashchenko, T. Metaksas, M. Oklander, O. Pankrukhin, E. Romat, T. Sachuk, D. Haider. At the same time, the notion "attractiveness as marketing influence object" is not clearly defined, the statements connected with the policy of marketing attractiveness are not formulated, marketing tools characteristic to modern marketing conceptions are not identified.

The aim of the article is a consideration the tools of formation and increase of territorial attractiveness within the framework of modern marketing conceptions, the role of marketing complex in the formation of territorial attractiveness will be discussed. Some economic categories formulating the notion of territorial attractiveness are specified; the offers to direct marketing efforts are formulated.

The concept of territorial marketing is considered as an effective tool to maximize the efficiency of territorial management, aimed at: meeting the needs of internal and external subjects of the territory in public goods, services, ideas; increase of the territory attractiveness (for habitation, for visiting, for activities, for investment); solution of the problems that most local authorities can not cope with traditional management methods; preservation of existing and formation of new competitive advantages of the territory; achievement of sustainable development of territorial systems; partnership development and harmonization of interests of socio-economic relations participants.

\section{Marketing concepts and the territorial policy}

In the works by I. Budnikevych (Budnikevich, 2012) the characteristics of territorial (municipal marketing, urban marketing) within the framework of manufacturing, trade, sale, marketing in particular (classical), social-ethic and partnership conceptions are identified. Each of the conceptions can be used at different stages of territorial development, extending the tasks and fields of marketing usage, changing its tools and methods. Thus, big cities of Ukraine have already started to realize the conceptions of classical 
marketing. Middlesized cities either finish to realize sales conception and form prerequisites of transformation to marketing conception or develop new advantages to involve economical agents to the city. Small towns mostly search for their own position within the goods conception or activate sales conception actual due to investors' migration out of big cities to more available land areas. The definition of marketing concept and systematic usage of its tools by territorial authorities allow to intensify the development of the territory (city, region).

Territorial marketing system allows to extend traditional approaches of regional and local authorities' policy, supplementing them with modern elements: image formation and development, complex attractiveness formation, target audiences eliciting and consecutive orientation on their needs satisfaction, ecological and social determination, the partnership of authorities and private business. Every member of territorial community and the subject of regional economy has his own opinion on desirable territorial attractiveness and it is important to achieve adequate consensus and social agreement towars aims, strategies, approaches, tasks, values, events, mechanisms of territorial development.

Marketing policy of attractiveness is a set of measures aimed at attracting the attention of target audiences to a certain territory (country, region, city, tourist territory, etc.), is developed and implemented by the territorial authorities with the active participation of community members and as a part of territorial programs and development strategies influences on business, investment, innovation, tourism, social, migration, environmental infrastructural attractiveness of the territory. This policy forms favorable business and innovative environments, it determines the income and direction of investments, tourist flows, qualified professionals and workers, it attracts the creative class to the city, reduces the outflow of local people from the region, especially the young and the middle class etc.

Territorial marketing allows to realize in practice the idea of social partnership, when interaction, approaches of social subjects to joint decisions of the tasks on the basis of balance, consensus, regulating society united by mutual values, becomes the main idea (Sachuk, 2009). Among the examples of conceptual practical realization of marketing in particular is Dresden's (Germany) "masterplan" promotion (Vizorek, 2010). Three interested parties take part in Dresden marketing simultaneously: local business communities, tourist agencies, municipal and local administration representatives managing all the processes. Alongside with that all main stockholders are involved into common work to realize innovative ideas. At the first stages the main task is to strengthen Dresden image as the city with attractive culture and economy, target audiences here are investors (tourists and local people).
O. Vizorek (Vizorek, 2010) presents a lot of marketing programmes realized in Dresden: The creation of city guide-book, the launch of the programme "November boredom overcoming", including numerous cultural and art events (115 disk jokeys and orchestras took part in the party "Unity. Dresden. Night"). A part of these events were aimed at establishing the connections with neighbouring countries - Czech Republic ("The Days of Czech culture"), Poland; organization of family leasure (the project "Children in the city"); the programmes of involving the students from other countries and regions (to help the talented youth in their studying and future work). Further stages of Dresden marketing programmes were connected with the realization of marketing partnership conception, allowing to unite all the stockholders into one common chain.

Marketing tools provide necessary informational resources, close cooperation of the departments responsible for foreign relations, public relations and city promotion with other departments, deputies, regional and state authorities. They help to establish interactive connections with all target audiences (population, investors, business), to form adequate distributing policy connected with available municipal services, to realize effective price forming methods, to produce new kinds of services, to change employees' organizational culture.

\section{The attractiveness of the territory and marketing tools}

Nowadays in the practice of domestic and foreign territorial marketing the tools of sales conception are still actively used. It predicts directed activity of territorial authorities to satisfy the needs of external and internal subjects for territorial investment attractiveness increase. The orientation on sales conception of territorial marketing is actively applied to attract new companies and trade chains of national and international format into the region or city, to increase territorial attractiveness for legal entities to invest assets and expend their market share, and for the population to realize labour potencial, and for tourist territories promotion into new markets.

Workshops are an interesting instrument of the increase of states and regions' attractiveness. For example, a representative office of the Ministry of Tourism of Israel in Ukraine alongside with the hotel Assocoation of Jerusalem and Tel-Aviv, with the assistance of TelAviv municipal Tourist office and the Company on the development of Jerusalem held in 2016 a workshop "Jerusalem and Tel-Aviv: two capitals - one country" (Israel is getting..., 2016), where they represented the program "City Break Jerusalem" as well. This program is produced especially for the tourists having arrived for more than three nights and can save greatly on the 
account of this proposal. In our opinion this experience is valuable for Chernivtsi city, the tourism of which is mostly positioned as a one-day tourism.

Marketing usage in this conception and those mentioned above (industrial, trade) is based on the complex of technical methods, skills and actions which can be successfully "sold", for example, specific territorial characteristics (especially geographic position, its resources, special objects making the territory more attractive for investors, tourists, visitors etc.). However, marketing activity within the framework of situational conceptions isn't of systematic character, marketing factors are underdeveloped, and the results of marketing research are understood as recommendations rather than the basis of territorial development strategies.

Discourses "city for tourists", "city for investors" are rather risky, as total enthusiasm of territorial authorities (state authorities of higher level as well) concerning the strategies of increasing tourist and investment attractiveness of the country, region or city focused on external target audiencies, can worsen living conditions and entrepreneurship activity of the territorial community (the pressure on public utilities increases: scavenging, watersupply and drenage system, gas and electric circuit, transport and its emissions into the air etc.). It can decrease local investors' activity (unjust access to resourses, more favourable conditions, lower expenses for foreign investors), change the attitude towards tourists (in western press the so-called "Paris syndrome" was discussed not once. They mean unkind attitude of Parisians to tourists from Japan. This fact forced local authorities to work out additional programs to increase Paris tourist attractiveness. Foreign tourists can apply to police officers who are able to speak two languages (there's an emblem of the state flag, representing the language of the country on their uniform). The policemen are ready to give necessary additional information (help to find the way to places of interest) and answer more delicate questions conserning theft or assault. Active also is the program $S$. A. V. E. (Systeme d'Assistance des Victimes Etrangeres, the system of help to suffered foreign tourists, available in 16 languages).

For such target audience as investors the most adequate tool is personal (direct) sale - "from person to person" (P2P). Personal contacts between local authorities, local business, consulting companies, scientists are the tools potencial investors prefer (Budnikevich, 2012). The increase of ukrainian cities and regions' investment attractiveness is possible only under the conditions of efficient work with investors (quickly, accurately, in a creative way), working out the events to return their trust, organizing the system of studying territorial marketing and branding for the authorities' representatives of different levels.

The tools of territorial marketing modern strategic conceptions allow to form and increase territorial attraction. According to a classic approach, territorial marketing as the philosophy of territorial management defines and satisfies target audiencies'needs through long-term competitive advantages' formation and the definition of prior approaches to develop territorial attraction. Philosophy of municipal bodies' functioning, based on social, ecological and economic attractiveness and provision of stable territorial development is founded on municipal marketing social-ethic conception.

Territorial marketing within the framework of partnership conception - is the philosophy of territorial (region, city) functioning, based on the formation, support and development of mutually beneficial longterm relations with the participants of this process, the aim of which is to create new common values to satisfy key needs of specific target audience, i.e. to form attractiveness. Marketing product consists of almost the same elements, but the demands to each element's characteristics depend on target marketing peculiarity. For example, population's demands in changing places provide public transport, pedestrian zones, parking places, airport, railway station are important for tourists and guests. Business demands to develop transport corridors, customs terminals, by-pass highways etc. Real property is useful for the population, industrial and commercial property is important for entrepreneurs, accomodations - for tourists, development for investors. Tourists evaluate natural resourses available for rest and recreation, but antrepreneurs appreciate all natural resourses etc.

City pricing attractiveness for guests and tourists is defined by the content of their consumer basket having a lot of modifications. "ECA International Worldwide Cost of Living Ranking" (www.eca-international. com) is held two times a year - in spring and autumn, standard consumer basket is evaluated for goods and services (the prices for 125 kinds of basic goods and servises, cost of livind included) bought by foreigners in 450 largest cities of the world. Mercer's "Worldwide Cost of Living survey" (www.mercer.com) includes fewer cities (209 cities in 2016, among them the most expensive in 2016 became Hong Kong, Kyiv occupies 176th place, among the cities of the former USSR the cheapest cities for habitation are Bishkek and Minsk). Mercer's survey is focused on large transcontinental corporations paying wages to their employees abroad, and the persons with high income. But there are different criteria of purchasing power for tourists. According to tourist portal Price of Travel (priceoftravel.com), european tourist "econom" basket includes such expenses as the price of accomodation per night in the cheapest hotel, motel or hostel, the cost of meals three times a day and two rides in public transport, visiting one of the city sights and three not expensive local beers or wines. The portal composed three star rating among the cities for an average tourist 
who neither economizes nor makes whoopee. It comprises: the cost of DBL accomodation per night in the cheapest three star hotel with good location and favourable comments, two 3 kilometer rides by taxi, cost of visiting of one of the city sights, meals in an inexpensive restaurant three times a day (drinks included, for abstainers - dessert or a local concert performance). According to the survey of 2015, Swiss Zurich has become the most expensive european city for tourists. Top five included Venice, Helsinki, London and Bergen. The cheapest city appeared to be Ukrainian Kyiv. Like the latter, Bucharest, Krakiv, Sophia and Belgrade were referred to as budget places for recreation. In 2011 searching system TripAdvisor started rating of the most expensive cities for travelers (https://www.tripadvisor.ru). They took into consideration the cost of accomodation in a 4 star hotel per night, pizza with cheese, onedry martini and 8 kilometer ride by taxi. The capital of Ukraine traditionally occupies high places in this rating.

Pricing attractiveness of entrepreneur sector is connected with the necessity to pay taxes (if state taxes don't depend on the city, local taxes, duties and payments have enough regulative influence), to hire employees of adequate qualification (expensive qualified workforce is an important vector of modern city development, forming consumers' demand for business product, and on account of savings allows financial sector to form investment resourses, expenses for public utilities, payments connected with running business (registration, functioning, liquidation). The regulation of prices, tariffs, income duties, licencing, benefits, subsidies, preferences, imposing penalties, granting preferencial credits and secured loans are the instruments of pricing marketing policy, concerning urban business sector. Though, setting prices, for example, for hotel accomodation, is not local authorities' duty, there are some methods allowing them to regulate this field as well. For example, the creation of preferencies to open inexpensive hotels (hostels), free information about hotels with reasonable prices in local tourist informational centres, the issue of a tourist ticket (Vienna ticket gives public transport preferences, those of visiting city attractions, Vienna Opera, visiting cafes, national restaurants etc.).

The quality of municipal management influences territorial products price. Negative emotions, arising from bureaucracy counteraction, the time lost in the local departments, decrease its attractiveness (Chernaya, 2005). It is very important to solve the problem of business expences working on municipal projects or their evaluation by local administrations, concerning credit granting, warranting, to create the conditions of investment attractiveness increase. Qualified management can form such conditions even if there are no resource prerequisites.

\section{Promoting the attractiveness of areas}

Before promoting the attractiveness of a territory it's necessary to understand its essence. We wholly agree with D Vizgalov, that "marketing for marketing" (Vizgalov, 2008) pursuing modern tendences, has no sense. Urban community must clearly realize what should be changed in its life as a result of marketing, that's why, it's necessary to define the strategies of urban development, specific model of its future, reflecting corresponding municipal marketing conception.

To announce the city "innovative directed" without envolving high technological firms, qualified employees, financial resources - is usual practice of homeland cities, strategic aims of which have innovative tinge, keeping pace with time. High salary, comfortable living conditions a specialist can get in a big city, these are classical competitive advantages (it is not marketing business, marketing can speak about it), but to transform city's disadvantages into strong points is marketing task: to transform city's provinciality into kind atmosphere, small dementions into compact infrastructure, absence of industrial production into ecological habitation, even low level of public transport development can become the basis for development, for example, the projects "urban bicycle", "a shop round the corner", "city promenade zones" etc. Strategic aim of all Ukrainian cities is to get the status of "tourist Mecca". But a question arises: "For what target audiences?", that's to say, the question of who we shall focus on is delayed. Though, it's this question that is significant in territorial marketing, because different marketing tools influence different target audiences. For example, to sell mass tourist product, it doesn't matter to whom, is the main task within the framework of premarket conceptions. Segmentation of specific target audiences happens within classical conception. For each audience the tourist product is worked out, the impressions are formed, adequate communicative means are chosen, varied prices are set, the attention is paid to logistic availability, the question of further visiting starts to be actual, social-ethic conception is forming "creative" tourist product, connected with events, ecological, ethic, comfort characteristics, additional social oriented value. Partnership conception actualizes interactiveness of tourist product, tourist's ability to influence its quality, quantity, characteristics, creates the efect of attraction on the basis of interaction with urban museums ("International Club of Hermitage Friends", "Great Karlovy Vary Forum"), municipality (different programs aimed at distance shortening between atourist and a resident, for example, through street performances).

Territorial marketing within the framework of modern conceptions should actively use new media platforms (social networks; microblogs; social networks' aggregation; event sites; informational sites; informational aggregators; social news sites; 
social layings; comment sites; reviwes; opinion sites; communicators) and base on electronic informational technologies; computer data fixing product price communicative advantages of target markets and their profile. These technologies allow a city to analyse marketing, collective specific information about consumers, form individual oriented product of the city.

Within the framework of partnership conception such factor of marketing mix as performance is also activated - presentation of municipal products to intrested groups and persons. The tools of this process are: direct translation of local authorities' meetings, mayor's public report; presentation of project results, marketing research, debates, round tables, talk show, press tours, public auctions and tenders, public hearings, charity events etc. For example, NY mayor Michael Bloomberg presented personally city budget three times: for local council, for other officials, for the press. Logic is simple: if the audience is aware of the forces moving local economy, it is possible to make clear tax and budget priorities. Mayor's meetings and personal contacts help to establish relations with different initiative groups and public organizations.

Nowadays the management function, important for classic marketing, stipulates not only marketing decision management, but rather the management of interrelations between local authorities, population, business, visitors and other target audiences of the city. Management function modification for the benefit of interaction gave chance, from communicative positions, to have a look at the technology of marketing as the mutually beneficial process of establishing, support and improvement of interrelations with buyers and other subjects to satisfy the aims of the parties of the operation. It's worth stressing, that the conception of marketing interrelation involves not only specialists in this sphere, but all municipality personnel, including higher authorities (mayor, executive committee, city council deputies). Thus, municipal marketing actualizes technologies of internal marketing, connected with hiring, studying and stimulating municipal employees to grant high level facilities to population, tourists and visitors, entrepreneurs and investors, public organizations etc. There appears also an integrant function within the partnership conception of municipal marketing, it allows to harmonize separate actions and tools with the aim to guarantee composite nature of territorial programmes and strengthening of attractiveness policies.

Marketing instruments form long-term relations, favourable to increase and transformation of territorial image, provide all subjects' loyalty, objects and contact audiences of the territories (including other cities, regions and countries). They are one of the most complex and effective mechanisms of forming and increase of attractiveness of the territory, its promotion in internal and external social-economical area.

\section{Conclusions}

The system of territorial marketing allows to widen traditional approaches of regional and local authorities' policy, supplementing them with modern elements and characteristics.

According to the marketing approach the territory attraction is a reflection of the degree of satisfaction of the needs and expectations of target audiences. Attractiveness is a potential of the territory from the viewpoint of the satisfaction degree and perspective growth of the needs of target audiences in case of their choice of territory (city, region, country) for activity (visiting, habitation, investment, etc.) taking into account the objectives and their capabilities. Based upon the priority target audiences and their needs there are made not only reasonable decisions in territorial management, but also territorial development strategies are developed.

Marketing policy of the territory attractiveness is a set of measures aimed at attracting attention of target audiences to a certain territory, it is developed and implemented by the territorial authorities with the active participation of community members and is an element of territorial programs and development strategies. In our opinion, it is necessary and possible to make the transition from situational concept of territorial marketing in Ukraine, where the goal is, for example, "earning the status of tourist city" or "attracting foreign investment", to strategically oriented concepts which are aimed at: in the classical concept - the status of a comfortable city for visiting, habitation, education, management, implementation of capabilities, investment; in the social and ethical concept environmentally, economically and socially sustainable city; in the concept of interaction - a partnership based on long-term relationships.

The marketing approach to the territory attractiveness in our opinion, should be seen as a transition to a longterm systematic management of territory development, based on a client-orientation and partnership, clear definition of the target audiences and their needs, formation of flexible regional policy, using both traditional and non-traditional tools for improving, maintaining, and sometimes decreasing attractiveness of the territory. Marketing efforts should focus on building a complex of long-term stable benefits, aimed at increasing the attractiveness of territorial product compared to other territories, not only for residents but also for other target groups - tourists, visitors, investors, population and entrepreneurs of other cities, subjects of regional, national and international level. Competitiveness of territories, in this case, provides with complementary social, business, investment, innovation, recreation, tourism, education, financial attractiveness, which will promote establishing the long-term partnerships with target audiences. 
As long-term issues that we are going to examine in our further studies are demarketing or counter marketing tools that will be directed on undesirable, for certain territories, target audiences(enterprises that reduce the ecological compatibility of territory, unfair investors, antisocial projects, sales of harmful products; radical organizations, etc.) and crisis marketing.

\section{References:}

Budnikevich, I. (2012). Municipal marketing: theory, methodology, practice. Chernivtsi: Chernivtsy national University, 645 p. (in Ukr.)

Chernaya, I. (2005). Territorial marketing. Vladivostok: VGUES. - 188 p. (in Rus.)

Israel is getting even closer (2016, June 10). Website «News of tourist industry». Retrieved from: http: // novostiturbiznesa.Info/article/izrail_stanovitsya_eshche_blizhe.html (in Ukr.)

Sachuk ,T. (2009). Territorial marketing. - SPb.: Peter., 2009, 368 p. (in Rus.)

Vizgalov, D. (2008). City marketing. M. : The Institute for Urban Economics, 110 p. (in Rus.)

Vizorek, E. Dresden: Uniting Past and Future. Marketing of Cities and Regions. - M.: CMD, 2010, p. 70-71. (in Rus., in Eng.)

The official website of the ECA International. Retrieved from: http://www.eca-international.com/home

The website of the Mercer Global. Worldwide Cost of Living survey. Retrieved from: http://www.mercer.com

The website of the Price of Travel. Retrieved from: http://www.priceoftravel.com

The website of the Tripadvisor. Retrieved from: https://www.tripadvisor.ru

\section{Ирина БУДНИКЕВИЧ, ИрИНа ГАВРИШ \\ СОВРЕМЕННЫЕКОНЦЕПЦИИ МАРКЕТИНГА КАКОСНОВАФОРМИРОВАНИЯИПОВЫШЕНИЯ ПРИВЛЕКАТЕЛЬНОСТИ ГОРОДОВ И ТЕРРИТОРИЙ}

Аннотация. Рассмотрены инструменты формирования и повышения привлекательности территорий (регионов, городов) в рамках современных концепций маркетинга, роль элементов комплекса маркетинга в формировании привлекательности территорий, уточнены отдельные экономические категории, которые формируют понятийный аппарат привлекательности территорий и сформулированы предложения по направлениям маркетинговых усилий. Методология. Теоретическими и методологическими основами исследования является работа ученых по проблемам маркетинга города, теория И. Будникевич согласно которой идентифицированы характеристики территориального маркетинга (муниципального маркетинга, маркетинга города) в рамках ситуативных и стратегических концепций. Авторы в процессе научного исследования использовали комбинацию из следующих методов: обобщение и научной абстракции для конкретизации понятийно-категориального аппарата; монографический метод - для представления мнения ученых по направлениям применения маркетинговых инструментов в процессах управления привлекательностью территорий; сравнительный анализ - для выявления особенностей использования инструментов и методов маркетинга в рамках различных концепций и на разных этапах развития территории. Практическая ценность. Было установлено, что система территориального маркетинга позволяет расширять традиционные направления политики привлекательности региональной и местной власти, дополняя их современными элементами и характеристиками. Сегодня в практике отечественного и зарубежного территориального маркетинга еще активно применяются инструменты ситуативных концепций, в частности сбытовой концепции, которая предусматривает ориентацию деятельности территориальных органов власти на удовлетворение потребностей внешних и внутренних субъектов для повышения инвестиционной привлекательности территории. Инструменты современных стратегических концепций территориального маркетинга позволят сформировать и повысить привлекательность территорий для определенных целевых аудиторий. Используя инструменты социально-этической концепции муниципального маркетинга можно акцентировать внимание целевых аудиторий на социальной, экологической и экономической привлекательности территории и обеспечить устойчивое развитие территории. Территориальный маркетинг в рамках партнерской концепции, как философия функционирования территории (региона, города) основанная на формировании, поддержании и развитии взаимовыгодных долгосрочных отношений с участниками процесса взаимодействия, позволит создать новые общие ценности, получать и распределять выгоду от этой деятельности. Развитие отношений между территорией и ее целевыми аудиториями определяет основу и формирует среду для принятия ими решения о проживании, посещения, ведение бизнеса, инвестирования и т.д., то есть формирует привлекательность конкретной территории (страны, региона, города или другого населенного пункта). Оригинальность. На основании этого исследования авторы 
предложили рассматривать маркетинговый подход к привлекательности территории (региона, города) как переход к долгосрочному развитию и системному управлению, на основе клиент-ориентированности и партнерства, четкого определения целевых аудиторий и их потребностей, гибкой региональной политики, используя как традиционные так нетрадиционные инструменты для формирования, улучшения, поддержки, а иногда и для уменьшения привлекательности территории средствами демаркетинга. Результаты. Определено, что в соответствии смаркетинговымподходом, привлекательность территории это совокупность устойчивых представлений о свойствах и признаках, критериях и условиях, возможностях и ограничениях, средствах и инструментах, которые обеспечивают удовлетворение и перспективу роста потребностей целевых аудиторий при выборе ими данной территории (региона, города) для активной деятельности и формируют их лояльность. Предложено понимать маркетинговую политику привлекательности территории как комплекс мероприятий, направленных на привлечение внимания целевой аудитории к определенной территории, она разрабатывается и реализуется территориальными органами управления при активном участии членов сообщества и является элементом территориальных программ и стратегий развития. Маркетинговые усилия должны быть сосредоточены на повышении привлекательности территории не только для жителей и бизнеса, но и для других целевых групп - туристов, посетителей, инвесторов, населения и предпринимателей других городов, субъектов регионального, национального и международного уровней. Инвестиционная, поселенческая, социальная, деловая, инновационная, туристическая, образовательная и др. привлекательность будет способствовать установлению долгосрочных партнерских отношений с целевыми аудиториями. Маркетинговые инструменты формируют долговременные отношения, которые способствуют повышению и трансформации имиджа территории, обеспечивают лояльность всех субъектов, объектов и контактных аудиторий территории, является одним из наиболее комплексных и эффективных механизмов формирования и повышения привлекательности территорий, ее продвижения во внутреннем и внешнем социально-экономическом пространстве. 